\title{
THE RELATIONSHIP BETWEEN \\ FAMILY ROLE AND SELF-CARE PATIENTS WITH SCHIZOPHRENIA
}

\author{
Permatasari Devi, Cucu Rokayah*, Ruhyat Ejeb \\ Program Studi Sarjana Keperawatan, Sekolah Tinggi Ilmu Kesehatan Dharma Husada Bandung, Jl. \\ Terusan Jakarta No.75, Cicaheum, Kec. Kiaracondong, Kota Bandung, Jawa Barat, Indonesia 40282 \\ *cucurokayah611@gmail.com
}

\begin{abstract}
Schizophrenia is a serious disease that results in psychotic behavior, disruption in processing information, and interpersonal relationships, the prevalence of schizophrenia in Indonesia, which is around 400,000 people, patients with schizophrenia tend to experience a decrease in self-care. This is due to the decline in some brain functions that are owned by these patients which make it difficult to express emotions, withdraw from the social environment, lose motivation, not interested in doing daily activities, and ignore personal hygiene, to self-care schizophrenic patients need a family role. This study aims to determine whether there is a relationship between the role of the family and self-care in schizophrenic patients in the Outpatient Installation of the Mental Hospital of West Java Province. This study uses a quantitative method with a type of descriptive correlation research, using accidental sampling technique and cross sectional approach. The sample in this study amounted to 296 patient families. This study used a family role questionnaire and self-care questionnaire. The independent variables studied were the role of the family and the dependent variable studied, namely self-care. Univariate analysis uses frequency distribution and bivariate using chi-square. The results showed that patients had a good family role of 151 respondents $(51.0 \%)$, and for self-care patients who needed as many as $125(42.2 \%)$ assistive devices. There is a significant relationship between the relationship of the role of the family and self-care in schizophrenic patients p-value $=0.006$.
\end{abstract}

Keywords: self-care, family role

\begin{tabular}{|c|c|c|}
\hline $\begin{array}{c}\text { First Received } \\
31 \text { October } 2019\end{array}$ & $\begin{array}{c}\text { Revised } \\
\text { 08 November } 2019\end{array}$ & $\begin{array}{c}\text { Accepted } \\
22 \text { November } 2019\end{array}$ \\
\hline $\begin{array}{c}\text { Final Proof Received } \\
25 \text { November } 2019\end{array}$ & & $\begin{array}{c}\text { Published } \\
30 \text { November } 2019\end{array}$ \\
\hline $\begin{array}{l}\text { How to cite (in APA style) } \\
\text { Devi, P,. Cucu, R,. Ejeb, R. (2019). } \\
\quad \text { schizophrenia . Indonesian J }\end{array}$ & $\begin{array}{l}\text { elationship between } \\
\text { l of Global Health }\end{array}$ & $\begin{array}{l}\text { role and self-care patients with } \\
h, 1(1), 21-30 \text {. }\end{array}$ \\
\hline
\end{tabular}

\section{INTRODUCTION}

Mental health is a condition where an individual can develop physically, mentally, spiritually, and socially so that the individual is aware of his own abilities, can deal with stress, can work productively, and is able to contribute to his community. Conditions of development that are not appropriate for individuals are called mental disorders (Law No. 18 of 2014 concerning Mental Health). Mental disorders according to the Guidelines for the Classification and Diagnosis of Mental Disorders (PPDGJ) III are syndromes of a person's behavior patterns that are typically associated with a symptom of distress in the body (impairment) in one or more important functions of humans, namely psychological functions, behavior, biological, and the disorder lies not only in the relationship between the person but also with the community (Maramis, 2009).

Mental disorders are currently experiencing a very significant increase, and every year in various parts of the world the number of people with mental disorders is increasing. 
Based on data from WHO in Yosep (2014), there are around 450 million people in the world who experience mental disorders. WHO states at least one in four people in the world has become a very serious problem. According to WHO (2016), there are about 35 million people affected by depression, 60 million affected by bipolar disorder, 21 million people affected by schizophrenia, and 47.5 million affected by dementia. The number of people with mental disorders in Indonesia currently is 236 million people, with the category of mild mental disorders $6 \%$ of the population and $0.17 \%$ suffer from severe mental disorders, $14.3 \%$ of them experience pasung. The prevalence of schizophrenia in Indonesia is 1.7 per 1000 population or around 400,000 people, or reaches 1.7 per mile, which means 1-2 people out of 1000 Indonesians experience severe mental disorders (Ministry of Health, 2014). Data from 2018 Riskesdas schizophrenia patients in West Java there are 55,133 residents.

According to Stuart (2013) Schizophrenia is a serious illness that results in psychotic behavior, disturbances in information processing, and interpersonal relations. The symptoms of schizophrenia can be divided into two groups, namely positive symptoms and negative symptoms. Positive symptoms consist of hallucinations, delusions, disturbed thoughts, and behavioral disorders, while negative symptoms consist of flat affect, self-care deficits, and withdrawal (Videbeck, 2008).

Patients with schizophrenia tend to experience decreased self-care. This is due to the decreased number of brain functions possessed by these patients which causes difficulty in expressing emotions, withdrawing from the social environment, loss of motivation, no interest in doing daily activities, and ignoring personal hygiene (Notoatmodjo, 2012). According to Johnson (1997) in Susanti (2010) for clients with schizophrenia it is very difficult to carry out self-care independently. Impaired cognitive function which is marked by poor orientation of reality resulted in decreased level of client awareness in self-care.

Self-care is one of the basic abilities of humans in meeting their needs in order to maintain their lives, health and well-being in accordance with their health conditions, a person is otherwise disrupted by his nursing if he cannot perform self-care (Kemenkes, 2010). Self-care deficits in schizophrenic patients occur due to changes in thought processes so that the ability to perform self-care activities decreases (Keliat, 2011). Some problems of self-care deficit include disruption of personal hygiene / bathing, inability to dress up or decorate, inability to eat / drink independently, difficulty in selfelimination, this requires the help of family or others to overcome it (Keliat, 2010).

Self-care in schizophrenic patients must involve the family. Because the family lives with the patient and knows better what the patient needs. The family is a group of people with the bond of marriage, birth and adoption that aims to create, maintain culture and enhance the physical, mental, emotional and social development of each family member (Friedman, 2013). The family plays a supportive role during the healing and recovery of sufferers. If the role is not carried out, then the success of healing and recovery is lacking, therefore how important is the role of the family (Friedman, 2010).

Some factors that can affect sufferers with lack of self-care at home include the role of family, knowledge, education, information, and socioeconomic (Wawan \& Dewi, 
2010). Role refers to some set of behaviors that are more or less homogeneous and normative than one's role in certain social situations. So, the role of the family describes a set of interpersonal behavior, traits, activities related to individuals in certain positions and situations (Hasriana, 2013).

The role of the family is a set of behaviors expected by others towards someone according to their position in a system (Mubarak, 2009). There are two classifications of family roles, namely the formal role of the family and the informal role of the family. The formal role of the family is the role of existing marital relationships in the family, while the informal role consists of the role of an intermediary that is the liaison when communicating in the family, the follower is passively accepting the ideas of others and the listener when iskusi or group decisions, caregivers are family members needed to care for and caring for other members in need and so on (Friedman, 2010).

The results of a preliminary study of 10 families who visited the outpatient of the West Java Provincial Mental Hospital found that 3 families said that in their home they played an important role in the daily needs of schizophrenic patients including their personal hygiene, and always provided food / drink, 2 families said that they only provide the facilities and do not assist in the self-care of schizophrenic patients. Five families said that they were not involved at all in the fulfillment of self-care schizophrenia patients such as bathing, dressing, eating and eliminating it, 2 out of 5 families said that the schizophrenic patient was an adult so he had to do his own needs including eating / drinking and dressing. The results of researchers' observations of 6 schizophrenia patients who came to the ambulatory care at the West Java Provincial Mental Hospital showed dirty nails, bad breath, smelly hair, and shabby clothes.

Based on the background above the research objectives is to knowing the relationship between family role and self care patient with schizophrenia used quantitative research method. Based on the description above, the research problem can be formulated as follows: "Is there a relationship between the role of the family and self-care in schizophrenia patients in the Outpatient Installation of the Mental Hospital of West Java Province?".

The Purpose of the Age knowing the relationship of the role of family with self-care in schizophrenia patients in the Outpatient Installation of Mental Hospital of West Java Province. Special Purpose to identifying the role of the family in schizophrenia patients in the Outpatient Installation of the Mental Hospital of West Java Province, to identifying self-care in schizophrenia patients at Outpatient Installation of Mental Hospital of West Java Province, to knowing the relationship of the role of family with self-care in schizophrenia patients in the Outpatient Installation of Mental Hospital of West Java Province. This research was conducted in July 2019 at the Outpatient Installation of the Mental Hospital of West Java Province, this research included in psychiatric nursing and family nursing.

\section{METHOD}

The research design used is descriptive correlational. This research is to find out the relationship between the role of family and self care in schizophrenia patients in outpatient psychiatric hospital in West Java Province. The approach used in this 
research design is cross sectional which is a study to study the dynamics of correlation or the relationship between the dependent variable and the independent variable by way of approach, observation or data collection at one time (Notoatmodjo, 2012). In this study, the data collection of independent variables, namely the role of the family and the dependent variable, namely self-care in patients with schizophrenia, were taken only once and at the same time.

Population is any large number of subjects that have certain characteristics (Sastroasmoro, 2011). The population in this study are families who care for and who live at home with schizophrenia patients who come to take patients to the Outpatient Installation of Mental Hospital of West Java Province, seen from outpatient medical records during January-December 2018, there are 13,544 outpatients with an average of 13,544 patients average per month is 1,129 patients. The sampling technique used in this study was by accidental sampling as many as 296 respondents. A data collection tool using a questionnaire. Operational definition for independent Variable: Family Roles is how does the family help schizophrenia patients in self care consisting of 3 aspects namely intermediaries, caregivers and followers. It is score Good, if the answer is $\geq$ median (37.00) and score Less: if the answer <median (37.00).Operational definition for Dependent Variable: Self-Care in Schizophrenic Patients is An action or ability to fulfill their daily needs such as personal hygiene / bathing, dressing, defecating and eating / drinking. It is score 0: fully independent, 1-4: need equipment, 5-8: semi-independent, 9-12: partial dependence, and 13-16: total dependence. Data were analyzed using frequency distribution and chi square test.

\section{RESULTS}

Table 1.

Characteristics of schizophrenic patient family respondents $(n=296)$

\begin{tabular}{cccc}
\hline & Category & $\mathrm{f}$ & $\%$ \\
\hline \multirow{4}{*}{ Age } & $17-25$ years old & 17 & 5,74 \\
& $26-35$ years old & 71 & 23,99 \\
& $36-45$ years old & 93 & 31,42 \\
& $46-55$ years old & 94 & 31,76 \\
\multirow{2}{*}{ Gender } & $>$ 65 years old & 1 & 0,34 \\
& Woman & 169 & 57,09 \\
\multirow{3}{*}{ Relationship with } & Man & 127 & 42,91 \\
patients & Son & 121 & 40,88 \\
& Husband & 72 & 24,31 \\
& Wife & 56 & 18,92 \\
& mother & 38 & 12,84 \\
\multirow{2}{*}{ Education } & Father & 9 & 3,04 \\
& Elementary school & 63 & 21,28 \\
& Middle School & 79 & 26,69 \\
& High school & 116 & 39,19 \\
& Diploma & 8 & 2,70 \\
& S1 & 30 & 10,14 \\
\hline
\end{tabular}

After conducting research on the relationship of the role of family with self-care in schizophrenia patients in the Outpatient Installation of Mental Hospital of West Java Province for 1 week, with this type of research using cross sectional research methods, 
data collected in the form of primary data obtained directly from respondents who deliver patients to the Outpatient Installation of Mental Hospital of West Java Province. The analysis of this study uses two analytical methods, namely univariate and bivariate analysis.

The highest category of respondents by age obtained the highest data in the age range 46-55 years that is as much as 94 respondents $(31.76 \%)$, the category of respondents based on gender obtained the highest data of women which is 169 respondents $(57.09 \%)$, the categories of respondents based on their relationship with Patients obtained the highest data of children that is 121 respondents $(40.88 \%)$, and the category of respondents based on education obtained the highest data of high school which is 116 respondents $(39.19 \%)$.

The table below shows the results of an analysis of the role of families with self-care schizophrenia patients who have done.

Table 2.

Correlation Between the Role of Families with Self-Care in Schizophrenia Patients $(n=296)$

\begin{tabular}{|c|c|c|c|c|c|c|c|c|c|c|}
\hline \multirow{3}{*}{$\begin{array}{l}\text { Role of } \\
\text { the } \\
\text { Family }\end{array}$} & \multicolumn{6}{|c|}{ Self care } & & & \multirow{3}{*}{$X^{2}$} & \multirow{3}{*}{$\begin{array}{c}P- \\
\text { Value }\end{array}$} \\
\hline & \multicolumn{2}{|c|}{$\begin{array}{c}\text { Full- } \\
\text { independent }\end{array}$} & \multicolumn{2}{|c|}{$\begin{array}{c}\text { Need } \\
\text { Equipment }\end{array}$} & \multicolumn{2}{|c|}{$\begin{array}{c}\text { semi- } \\
\text { independent }\end{array}$} & \multicolumn{2}{|c|}{ Total } & & \\
\hline & $\mathrm{f}$ & $\%$ & $\mathrm{f}$ & $\%$ & $\mathrm{f}$ & $\%$ & f & $\%$ & & \\
\hline Baik & 47 & 15,9 & 53 & 17,9 & 51 & 17,2 & 151 & 51 & & \\
\hline $\begin{array}{c}\text { Kurang } \\
\text { Baik }\end{array}$ & 37 & 12,5 & 72 & 24,3 & 36 & 12,2 & 145 & 49 & 6,546 & 0,038 \\
\hline
\end{tabular}

Based on the above table that has been done the recode method can be seen that the highest results indicate the role of a good family and self care requires equipment that is 53 respondents $(17.9 \%)$ and the lowest results indicate the role of the family is not good and self-care semi-independent namely 36 respondents $(12.2 \%)$.Chi square test results showed $\mathrm{p}$ value $=0.038<\alpha(0.05)$, then Ha was accepted. This means that there is a significant relationship / correlation between the role of family and self-care in schizophrenic patients in the Outpatient Installation of a Mental Hospital in West Java Province.

\section{DISCUSSION}

Based on the results of research conducted on the relationship of the role of family with self-care in schizophrenic patients in the Outpatient Installation of Mental Hospital of West Java Province, then a discussion of the results of the study is as follows:

\section{Role of the Family}

The results showed respondents who had a family role in the good category 151 respondents $(51.0 \%)$ and who had a family role in the poor category 145 respondents (49.0\%). This shows that of the 296 respondents, respondents who got a good family role $(51.0 \%)$. The results of research conducted at the Outpatient Installation of Mental Hospital of West Java Province, found that most families play a good role in schizophrenia patients because the attitude of the family is also good so that it affects the role of the family. This shows that the role refers to some set of behaviors that are 
more or less homogeneous and normative than the role of a person in certain social situations (Hasriani, 2013).

The results of this study are the same as the research of Budi, Sari and Hartanto (2014) entitled the role of the family in self-care of Schizophrenia patients in the Polyclinic Clinic of the Medan Provonsi Mental Hospital. , the role of families with enough categories is 16 people (40\%), and the role of families with less categories is 3 people (7.5\%). Because the study has the same characteristics of respondents, the most respondents with an age range of $40-48$ of 16 people (40\%), and the most education is high school.

Based on research on the role of families with self-care in schizophrenia patients in the Outpatient Installation of Mental Hospital of West Java Province, researchers analyzed that schizophrenia patients really need the participation of their families and people around them, so that schizophrenic patients feel that they are highly valued and cared for. But often schizophrenia patients feel themselves less aware of the role of the family itself, which includes formal and informal roles.

\section{Self-Care Schizophrenic Patients}

The results showed as many as 84 patients (28.4\%) full self-care, 125 patients $(42.2 \%)$ needed equipment, and 87 patients $(29.4 \%)$ were semi-independent. This indicated that of the 296 respondents most of the patients schizophrenia perform self-care by needing assistive devices (42.2\%).

The results showed that most of the patients in the Mental Hospital Outpatient Installation needed assistive devices to perform self-care. This is supported by the theory according to Johnson (1997) in Susanti (2010) for clients with schizophrenia it is very difficult to carry out self-care independently. Impaired cognitive function which is marked by poor orientation of reality resulted in decreased level of client awareness in self-care.

The results of this study are in line with the research of Andayani (2012) found that at the level of self-care ability: bathing is the most respondents who need equipment or assistive devices as many as 24 people (40.7\%), the level of self-care ability: dressing are respondents who need equipment or assistive devices as many as 24 people $(40.7 \%)$, the level of self-care ability: eating are respondents who need equipment or assistive devices as many as 36 people $(61.0 \%)$, the level of self-care ability: elimination are respondents who need equipment or assistive devices as many as 39 people $(66.1 \%)$.

Researchers argue that this is because the family considers that patients with schizophrenia often neglect and there is no motivation for self-care, so the family must play a direct role to help patient self-care. Judging from the relationship with patients most of them are children (40.88\%) because they feel they still have a responsibility to parents to care for and look after it, although the level of education does not affect the self-care of schizophrenia patients, because the level of education is mostly high school $(39,19)$, with the most sex, namely women and the age range $46-55$ years, namely 94 respondents $(31.76 \%)$ because adulthood is more productive in helping self-care 
schizophrenia patients compared with old age, because if the age gets older then for carrying out any activity will be reduced and limited, so it will not carry out its role.

\section{Relationship of the Role of Family with Self-Care in Schizophrenia Patients}

The results showed that the role of the family affected the self-care of schizophrenia patients. This indicates that of the 296 respondents, respondents who had a good family role and self-care needed equipment. P-value $=0.038<\alpha(0.05)$, this means there is a significant relationship between the role of family and self-care in schizophrenic patients.

The results of this study are the same as the research conducted by Pratama (2018) which shows that good family support with good self-care were $71(49.0 \%)$, self-care was poor $(1(0.7 \%)$. Whereas adequate family support with good self-care was 28 $(19.3 \%)$, unfavorable support was $25(17.2 \%)$. Poor family support with good self care as much as $3(2.1 \%)$ and poor self care as much as $17(11.7 \%)$. From the results of calculators using the chi-quare obtained $\mathrm{p}$ value $0,000(\mathrm{P}<0.05)$ which shows there is a relationship between family support and self-care in patients with mental disorders at RSUD Dr. H. Soewondo Kendal.

The results of this study are in line with the research of Wibowo (2009) found that $\rho$ value $0.04(<0.05)$ explains that there is a relationship between family support and selfcare behavior in hallucinatory patients. The role and involvement of the family is very important for patients with mental disorders because the family's role is very supportive for the healing of patients because the family is able to provide trust and a good attitude for his family. The family has the function of providing affection, security, trust and preparing roles in the community. The family is a unit of a system, which is interdependent with each other.

The results of this study were reinforced by Nurjamil (2018) that the role of the family was very valuable and would add to the tranquility of his life. The role of the family given to patients with love and attention will be able to understand its meaning well as a supporter / sustainer of his life. The researcher believes that the role of the family is very important in healing the patient, because the family lives in the same house with the patient, and the family really understands what is needed by the patient, with the role of the patient's family will feel that he is highly valued and loved. So, it is clear in theory the role of the family is very influential in the self-care of schizophrenic patients. So the researchers analyzed the tendency for the better the role of the family, the better self-care schizophrenic patients.

\section{CONCLUSION}

The role of the family in schizophrenic patients with a good family role category is 151 respondents with a percentage (51.0\%). This means that the family is very concerned about family members who are sick. Self-care in schizophrenic patients shows the results of 125 patients with a percentage (42.2\%) needing equipment. This means that families are involved in self-care schizophrenia patients. There is a significant relationship between the role of family with self-care in schizophrenic patients in the Outpatient Installation of Mental Hospital of West Java Province with a P-value of $0.038<0.05$. 


\section{REFERENCES}

Andayani. (2012). Hubungan Karakteristik Pasien Skizofrenia dengan Tingkat Kemampuan Perawatan Diri Di Ruang Rawat Inap Pskiatri Wanita Rumah Sakit Marzoeki Mahdi Bogor. Universitas Indonesia.

Friedman, M. (2010). Buku Ajar Keperawatan Keluarga: Riset, Teori, dan Praktek. Edisi ke-5. Jakarta; EGC

Friedman. (2013). Keperawatan Keluarga. Yogyakarta: Gosyen Publishing.

Hartanto, Budi, dan Sari . (2014). Peran Keluarga dalam Perawatan Diri Pasien Skizofrenia di Poli Klinik Rumah Sakit Jiwa Daerah ProvonsiMedan. Diakses pada tanggal 24 Februari 2018. Tersedia dari: URL: https://ejurnal.stikesrshajimdn.ac.id/download.php?file=esti.pdf

Hasriana, D.,Sri Anggriani. (2013). Penderita Gangguan Jiwa Di Rumah Sakit Khusus Daerah Provinsi Sulawesi. Jurnal keperawatan Volume 2 Nomor 6.

Keliat dan Akemat. (2010). Model Praktik Keperawatan Profesional Jiwa. Jakarta : EGC.

Keliat, Budi Anna. (2011). Keperawatan Kesehatan Jiwa Komunitas. EGC, Jakarta.

Kementerian Kesehatan RI. (2010). Profil Kesehatan Indonesia Tahun 2009. Jakarta: Depkes RI

Kementerian Kesehatan RI. (2014). Undang Undang No 18 Tahun 2014 Tentang Kesehatan Jiwa.

Kementrian Kesehatan RI. (2018). Riset Kesehatan Dasar; RISKESDAS. Jakarta: Balitbang

Maramis. (2009). Catatan Ilmu Kedokteran Jiwa. Edisi 2.Surabaya: Airlangga.

Mubarak, W, I \& Chayatin, N 2009. Ilmu Keperawatan Komunitas Pengantar dan Teori. Jakarta : Salemba Medika.

Notoatmodjo, S. 2012. Metodologi Penelitian Kesehatan. Jakarta: Rineka Cipta.

Nurjamil. 2018. Hubungan Peran Keluarga dengan Kepatuhan Minum Obat Pasien Skizofrenia di Poliklinik Jiwa RSAU dr. M. Salamun. STIKes Dharma Husada Bandung.

Nursalam. 2013. Metodologi Penelitian Ilmu Keperawatan: Pendekatan Praktis : Jakarta : Salemba Medika.

PH, L., Hermanto, H., \& Pratama, N. (2018). Dukungan Keluarga dengan Perawatan Diri pada Pasein Gangguan Jiwa di Poli Jiwa. Jurnal Kesehatan Manarang, 4(1), 11 - 17. doi:10.33490/jkm.v4i1.54

Sastroasmoro, S dan Ismael, S. 2011. Dasar-dasar Metodologi Penelitian Klinis. Binarupa Aksara : Jakarta. 
Stuart, G. W. \& Sundeen. 2013. Buku saku keperawatan jiwa (edisi 3), alih bahasa, Achir Yani, editor Yasmin Asih. Jakarta: EGC.

Sugiyono. 2011. Statistika untuk Penelitian, Bandung, Alfabeta.

Susanti. 2010. Defisit Perawatan Diri pada Klien Skizofrenia: Aplikasi Teori Keperawatan Orem. Universitas Indonesi: Depok. Jurnal Keperawatan Indonesia, Vol 13 No. 2. Juli 2010.

Swarjana, Ketut. 2012. Metodologi Penelitian Kesehatan, Yogyakarta: ANDI

Videbeck, Sheila L. 2008. Buku Ajar Keperawatan Jiwa. Jakarta: EGC

Wawan dan Dewi. 2010. Pengetahuan,Sikap, dan Perilaku Manusia. Nuha Medika: Yogyakarta.

Yosep, Iyus. 2014. Keperawatan Jiwa (Edisi Revisi). Bandung: Refika Aditama 
Indonesian Journal of Global Health Research, Vol 1 No 1, November 2019, pp. 21 - 30 Global Health Science Group 